\title{
Sarty’s Initiation in Faulkner’s Barn Burning*
}

\author{
LIU Ke-dong, LIN Shi-rong \\ Harbin Institute of Technology, Harbin, China
}

\begin{abstract}
Barn Burning (1939), one of William Faulkner's outstanding short stories, is not only about the struggles between different classes, but also depicts the boy's initiation into manhood after he sees his father's rash and irrational revenge activities. The boy protagonist's constant dilemma is between whether to protect his father's authority due to the old fierce blood tie or to disclose his father's quasi-criminal attempts according to his own standard of justice. Based on close reading of the text, this paper aims to make a detailed analysis of the different factors (paternalism and his own idea of justice) that influence the boy's choices at different stages. After the long-time struggle, the boy finally chooses to follow his own standards of right and justice, which signifies his gradual initiation into manhood.
\end{abstract}

Keywords: Barn Burning, justice, blood tie, initiation

\section{Introduction}

William Faulkner was the winner of the 1949 Nobel Prize of Literature for "his power and artistically unique contribution to the modern American novel” (MEI, 2011, p. 1). He is a writer of the south, whose experiences of living there influence him a lot and provides him with a large number of source materials of writing. His special interests lie in his probing into the life of the south under the influence of the corrupt traditional ideology.

Told from the third person point of view of Sarty, Barn Burning (1939) is a good story showing life of the south. In addition, it presents the reader with a boy's gradual psychological growing up after a harsh dilemma. "On the one hand, Sarty wants to stay loyal to his family; on the other hand, Sarty's sense of justice begins to grow up” (PI, 2010, p. 104).

Experiencing the three stages-blind conformity to father's authority, struggle between his cognition of justice and blood tie, and resolution about justice-Sarty matures into manhood and chooses to stick to his own standards of justice.

\section{Sarty's Blind Conformity to Father's Authority}

In the early stage, the protagonist, Sarty, is always in blind respect to any of his father's behaviors, whether they are right or wrong. In Barn Burning, the story unfolds with the situation in the court. Mr. Harris accuses Abner Snopes for burning his barn. To testify for his father's crime of burning the barn, the boy is asked to come to the court. In order to keep his father's dignity and reputation, the boy says nothing. He never agrees with his

\footnotetext{
* This paper is a gradual achievement in the research project "A Study of Modern and Contemporary Short Stories Through the Lenz of Defamiliarization" supported by "the Fundamental Research Funds for the Central Universities” (Grant No. HIT. HSS. 201132).

LIU Ke-dong, professor, English Department, School of Foreign Languages, Harbin Institute of Technology.

LIN Shi-rong, M.A. candidate, English Department, School of Foreign Languages, Harbin Institute of Technology.
} 
father's primitive revenge activities, but in order to obey the religious teachings and be an obedient son, he has to stay mute and blind. His early conformity results from the two major aspects.

Individually, as an immature little boy, Sarty's early blind conformity is because of his own standards of right and justice having not been formed. In this period, the boy is only a timid small child and is awed by his father's authority. The little son, Sarty, idolizes his father's authority on account of the father's taking part in the Civil War. Faulkner does not provide us with any details about how brave the father behaves in the war in this novel. However, the boy respects his father beyond question. “'He was brave! He was! He was in the war! He was in Colonel Sartoris' cav'ry!” (Faulkner, 1990, p. 517). Due to Sarty's respect, he is taught to be a man in the light of his father's criteria. His father "attempts to teach his son to be a man in the postbellum South by revealing to him the injustices of the sharecropping system” (Joiner, 2010, p. 31). The wealth achieved by the dominant class is through immoral means, such as exploiting the poor farmers. "The farmers at that time suffered from the pressure both mentally and physically” (B. LIU, ZHAO, \& J. LIU, 2012, p. 62). In order to express the fury towards the rich, the boy's father, Abner, threatens to violate others' legal rights and property. Though the father's alleged barn burning activity has significance in fighting against the inequality in society, it is rough and extreme. He dares not speak out the truth that his father has burned Mr. Harris' barn. His father is also quite confident that his son will not betray him so that his father does not even look at him in the court. The boy thinks that: "He aims for me to lie, he thought; again with that frantic grief and despair. And I will have to do hit" (Faulkner, 1990, p. 504). He treats all those who may bring harm to his father as the potential enemies. He thinks that to be loyal to his father means to be mute. On the contrary, speaking out the truth in the court means to betray his father. He is manipulated by an invisible hand that compels him to be obedient even when facing his father's alleged violation of others' legal rights. What is ridiculous here lies is that the boy's father names him Colonel Sartoris Snopes, a symbol for justice and courage, but the boy dares not utter truth that he has seen the burning. His cowardice and silence lie in his fear towards the authority of his father.

Socially speaking, Sarty's early blind loyalty to blood tie is shaped by the pervasive influence of Puritanism and paternalism. Puritanism and paternalism were the two dominant ideologies in American South from the 17th century to the 19th century. The American South is looked upon as the "bible belt". The doctrine and ideology of Puritanism are deeply rooted in people's mind. In accordance with the basic spirit of the doctrine, puritans should respect father's absolute authority, and other members must be submissive to the head of the family, as to God. Paternalism stemmed from the economic pillar in the south of America where the economy was highly reliant on the plantation. Cash (1941) once said that "paternalism grew out of the necessity to justify and perpetuate the plantocracy on which the economic system of the south was based" (p. 211, as cited in MEI, 2011, p. 27). Since fathers are the main breadwinners and labor force of the whole family, they are the center and able to set down rules according to their own will, though some of them might be a little bit paranoid, as in this case. No matter what they do or how they behave, their words are so powerful that others must obey without weighing them being right or wrong. "Taking the decay and corruption of the South after the American Civil War as a background, Faulkner portrayed the inevitable tragedy when the traditional values meet the individual standards of right and justice” (MEI, 2011, p. 1). Faulkner is reliant on biblical themes in dealing with the relationship between father and son. Anyone that is against the authority of the father and betrays the family would suffer greatly and be punished due to their grave sin. Abner is a 
representative of the bigoted Southern father. In the 1920s and 1930s, different from the industrial society in the north, the American South was mainly an agricultural society whose economic foundation is plantation economy. Based on this kind of social structure and economic style, it is not hard to understand fathers, as the main labor force, are the indispensable part of the family. The duty of teaching the boy to be a man also falls on the father's shoulder. Strong emphasis is put on the family blood tie by the father. Nothing is more important than a solid and steady family. The main didactic teaching of Abner's moral lessons lies in the reinforcement of the idea of being loyal to family blood tie. Abner often says: "You are getting to be a man. You got to learn. You got to learn. You got to learn to stick to your own blood or you ain't going to have any blood to stick to you" (Faulkner, 1990, p. 506). It is obvious that when Sarty is young, what fills his mind is the typical puritan and patriarchal ideas. At that time, Sarty thinks that his father is helping him to understand the family responsibility and he agrees with what his father says.

Under this ideological suppression and due to his own immaturity, Sarty chooses to keep quiet at first. Sarty admires his father's authority and respects his father's core status in the family. He sees more shining points in his father, such as his courage in fighting against the imbalance of social class. Though Sarty finds something wrong with his father's behavior, it is impossible for a tractable little boy to question and challenge the father's decision. Sarty's blind conformity, at this stage, to the father's power is under the impact of traditional ideology, such as Puritanism and paternalism. In addition, the conformity is also due to his own lack of criteria of judging. The relationship between the father and the son still remains to be absolute obedience.

\section{Sarty's Struggle Between His Own Cognition of Right and Justice, and the Fierce Blood Tie}

In the second stage, Sarty’s sense of social responsibility and human integrity is gradually awakened. For the first time, the boy's gradual growing-up conscience as an independent human being meets the the society's pressure of judging a good son. Though Sarty still lacks firm resolution in stopping his father's barn burning activity, his own cognition of right and justice sprout in this stage.

This cognition firstly sprouts in his complex inner activities. Though he defends for his father in the court, he is eager to get rid of the sense of crime. Psychologically, he is somewhat like cheese, which is a metaphor indicating that he is stuck between the two different standards and unable to jump out of the harsh dilemma. "The fluid world, rushed beneath him again, the voices coming to him again through the smell of cheese and sealed meat, the fear and despair the old grief of blood" (Faulkner, 1990, p. 504). This description is in fact about the psychological activity of boy. The complex inner feelings of Sarty are presented. All these inner activities pave way for his later real action of trying to persuade his father.

His sprouting cognition also lies in his positive action. He begins to persuade his father to stop the cruel and primitive behaviors of burning the barns of the rich. Nevertheless, his father does not accept the boy's advice. The father still acts according to his own will. He is still nonchalant about the fact that he has soiled Major de Spain's rug. He places his dignity upon a small material ruin, disregarding his family having to clean the deluxe rug again and pay a high price for what he has done:

Watching him, the boy remarks the absolute undeviating course which his father held and saw the stiff foot come squarely down in a pile of fresh droppings where a horse has stood in the drive and which his father could have avoided by a simple change of stride. (Faulkner, 1990, p. 508) 
The boy protagonist Sarty wishes and believes that his father's could drop his habit:

\footnotetext{
Maybe this is the end of it. Maybe even that twenty bushels that seems hard to have to pay for just a rug will be a cheap price for him to stop forever and always from being what he used to be. (Faulkner, 1990, p. 512)
}

In this stage, the boy does respect his father's authority in the family, but meanwhile he starts to feel that he can not be blind towards the father's impetuous and even criminal means of hurting others. He is not absolutely sure whether his father could stop the behavior, but one could easily tell that after the inner torture, the boy starts to take actions to persuade his father according to his own standards of justice.

\section{Sarty's Resolution and a Contemporary Look at Justice}

In the final stage, Sarty takes firm action to end his fathers barn burning activity. His own standards of right and justice finally conquer the old fierce blood tie. Facing his father's constant ruthless behavior, Sarty cannot stay mute and be loyal to his father; on the contrary, he sticks to justice and becomes rebellious towards the old tradition. When he is aware that his father would initiate a new round of barn burning activities, he informs the tenant Major de Spain with the word "barn", which serves as the direct cause of the final conflict. From the surface, one may say that Sarty’s telling the truth to the Major de Spain leads to his father's death. In fact, what he aims for is to protect his father. He wants his father to end the bad habits and leads a stable and legal life.

However, what exceeds his expectations is that when he informs Major de Spain, the major is ferocious. He not only wants to catch the boy, but also wants to put his father to death. Sarty then crazily goes to find his father, but it is too late. He hears the gun shoot which is an indication of his father's death. After his "betrayal" towards his father, he leaves his family. Undoubtedly, it is extreme for Sarty's father to burn barns in retribution to the wrongs he receives, but the law is not against prejudice and does not stipulate any punishment for the rich who scorn and exploit the poor. "The sheer gap between the rich and the poor would led to a hatred toward the rich” (ZHENG, 2006, p. 72). Justice in the then southern society needs to be questioned. Since the colonial period, the Southerners have established the plantation-oriented economic system. Within this sort of economic system, southerners firmly believe that the rich are the ruling class of the whole society, for the tremendous wealth they achieve. It is natural for the impoverished group of southerners to accept that they are inferior to the rich. "The impoverished condition of the family pushed them to struggle hard to survive in a rich-dominant society” (FENG, 2006, p. 75). All the social norms and even laws are made according to the wills of the rich group. The beginning of the story is in the so-called justice of the Peace's court. The justice asks Mr. Harris, who claims that his barn is burned by Abner, to provide the evidence. However, the evidence Mr. Harris gives is not truthful or convincing. Nobody can judge for sure the barn burning activity is done by Abner, but Abner is sentenced to leave the country and not to come back. In addition, the old rug of the Major de Spain is said to be worth of 100 dollars. The justice asks him to charge 20 bushels of corn. In fact, the old rug is not worth that much. Twenty bushels of corn can only add to the burden of an ordinary family that is reliant on farming. When asking him to pay for the rug, the justice is quite scornful. "You never had a hundred dollars. You never will” (Faulkner, 1990, p. 511). At last, the boy informs the Major de Spain that his father may start a new round of barn burning activity. The intention of the boy is to lighten the father's guilt. However, the 
result turns out to be a totally violation against the boy's will. The Major de Spain even wants to catch the honest boy who actually has nothing to do with the crime. Meanwhile, the boy hears two shots that indicate the father's and brother's death when he is running away.

All the above provides evidence to say that justice in the south only guarantees the benefit of the rich, and meanwhile it is the violation of the poor. It is not the integrity in real sense, but again it mocks the inequity of the society. All these happenings mirror the lack of justice in the then American South. The so-called peace and justice are largely in accordance with the rich and authority.

\section{Conclusions}

Barn Burning successfully depicts the process of a boy's initiation into maturity. It seems that there is not a final compromise between blood tie and justice in that specific historical period. Through the work presented by Faulkner, the life of the southerners who live under the influence of corrupt traditional ideology and family power is vividly mirrored. The relationships between family members are off the right path of harmony and warmth. Instead, both fathers and sons become the victim of the inhuman and unconcerned southern society. It is a habit for fathers to conform to the old fierce blood tie blindly and impose his own idea on his son, hoping that the sons could pass on the so-called tradition but obviously dregs of the southern society. Sons fall into the constant struggles between his own standards as an independent person and the thoughts rooted by fathers and society. Nobody will be happy and peaceful in such a society. Due to the suppression and neglect of individual conscience, great gaps are formed between the new generation and the traditional family. What is worse, these gaps can not be bridged in a short time and can only end up with a tragedy. On the one hand, to stick to the former, it means to be blind towards the father's extremeness and meanwhile to violate Sarty's own consciousness. On the other hand, to pursue the awareness of mild justice, Sarty has to betray his family. After a long period of mental torture, the boy's maturity and consciousness finally breaks the bounds of the traditional fierce blood tie. A man is never taught to be, instead, it is the human nature of right and integrity that works. Sarty finally grows from innocence to experience and also from immaturity to maturity. It is never known how many steps a man must take before he becomes a man in the real sense.

\section{References}

Cash, W. J. (1941). The mind of the south. New York: Vintage Books.

Faulkner, W. (1990). Barn burning. In R. V. Cassill (Ed.), The Norton anthology of short fiction (4th ed.). New York: W. W. Norton \& Company.

FENG, B. (2006). A novel and a nation: The change of the production relations and Abner's barn burning. Journal of Ocean University of China (Social Sciences Edition), (6), 75-77.

Joiner, J. J. (2010). Constructing black sons: William Faulkner’s “Barn Burning” and Flannery O’Connor’s “The Artificial Nigger”. Flannery O’Connor Review, (8), 31-47,166.

LIU, B., ZHAO, S., \& LIU, J. (2012). A multi-perspective interpretation of the father-son relationship in a Yoknapatawpha [story]. Barn burning. Journal of Xi'an University of Architecture and Technology (Social Science Edition), 31(2), 61-67.

MEI, D. (2011). Father-son relationship in Faulkner's major works (M.A. thesis, Suzhou University).

PI, A. H. (2010). The struggle between justice and blood tie. Journal of Central South University of Forestry and Technology, 4(2), 103-105.

ZHENG, L. Z. (2006). Requirement of reducing the gap between rich and poor in a harmonious society. Journal of Yunnan School of Administration, (2), 72-75. 